\title{
Metabotropic Glutamate Receptors as Targets for Multipotential Treatment of Neurological Disorders
}

\author{
Kimberly R. Byrnes, David J. Loane, and Alan I. Faden \\ Department of Neuroscience, Georgetown University Medical Center, Washington, DC 20057
}

\begin{abstract}
Summary: Glutamate is a major excitatory neurotransmitter in the CNS that is involved in numerous cellular functions, including cell death and survival. Metabotropic glutamate receptors (mGluR) are G-protein coupled receptors that have been classified into three groups on the basis of signal transduction pathways and pharmacological profiles. Group I, II, and III mGluRs are found on cell types within and peripheral to the CNS, including neurons, microglia, astrocytes, oligodendrocytes, T- and B-cell lymphocytes, osteoblasts, hepatocytes, and endothelial cells, among others. These receptors have a number of effects on cells that can influence outcome after trauma, including reducing neuronal and
\end{abstract}

oligodendroglial cell death, inflammation, and endothelial permeability. Thus, mGluRs are a promising multipotential therapeutic approach. Because the pathology of CNS trauma and neurodegeneration is multifactorial (including, for example, oxidative stress, mitochondrial breakdown, and inflammation), therapies that serve to modulate multiple pathophysiological pathways may prove more effective than those directed at a single target. This review examines the multipotential therapeutic utility of mGluR modulation in acute and chronic injury and neurodegeneration. Key Words: Astrocytes, inflammation, metabotropic glutamate receptors, microglia, neuron, neuroprotection.

\section{INTRODUCTION}

Glutamate is a major excitatory neurotransmitter in the CNS that regulates cellular and synaptic activity, plasticity, cell death and survival, learning and memory, pain perception, and motor activity. ${ }^{1}$ Glutamate receptors are present in two forms: ionotropic and metabotropic. Ionotropic receptors, such as the NMDA and AMPA receptors, are ligand-gated ionic channels, whereas metabotropic glutamate receptors (mGluR) are G-protein coupled receptors. The latter have seven transmembrane domains and have been classified into three groups on the basis of signal transduction pathways and pharmacological profiles (Table 1).

Group I mGluRs comprise mGluR1 and mGluR5. They are localized in the postsynaptic density area at excitatory synaptic sites and function through $\mathrm{G} \alpha_{\mathrm{q}}$-proteins (FIG. 1). Group I agonists cause activation of phospholipase C (PLC), leading to release of calcium and activation of protein kinase $\mathrm{C}(\mathrm{PKC}) .^{2}$ Downstream signaling pathways include mitogen-activated protein

Address correspondence and reprint requests to: Kimberly R. Byrnes, $\mathrm{Ph} . D$., Georgetown University Medical Center, Department of Neuroscience, Research Building, Room EP16A, 3970 Reservoir Rd., NW, Washington, DC 20057. E-mail: krb27@georgetown.edu.
(MAP) kinases, ERK1 and ERK2, which can be inhibited by mGluR5 and mGluR1 antagonists such as MPEP and CPCCOEt. ${ }^{2,3}$ Although less well studied, mGluR1 and 5 have been identified on other cell types including microglia, astrocytes, and oligodendrocytes.

Group II and III mGluRs are primarily localized presynaptically and are negatively coupled to adenylate cyclase (FIG. 1). Activation of these receptors results in feedback inhibition of glutamate release, through the inhibition of voltage-gated calcium entry into the cell. Similar to mGluR1 and mGluR5, group II and III mGluRs have also been identified on astrocytes and microglia.

After CNS trauma, the extracellular concentration of excitatory amino acids, including glutamate, is increased. ${ }^{4,5}$ The expression of mGluRs are also altered by CNS trauma; group II mGluRs are reduced after spinal cord injury and traumatic brain injury, ${ }^{6-8}$ whereas mGluR1 is increased rostral and caudal to the injury site after spinal cord injury, and mGluR5 remains unchanged. $^{7}$

Multipotential treatments have become more attractive therapeutic strategies. Several recent review articles have emphasized the potential of multifunctional drug approaches. ${ }^{9-11}$ Because the pathology of CNS trauma and neurodegeneration is multifactorial, therapies that serve 
Table 1. Characteristics of Metabotropic Glutamate Receptor Groups 1-III

\begin{tabular}{|c|c|c|c|c|c|}
\hline mGluR Group & Subtype & Location & $\begin{array}{l}\text { Transduction } \\
\text { Mechanism }\end{array}$ & Agonists & Antagonists \\
\hline Group I & $\begin{array}{l}\text { mGluR1 } \\
\text { mGluR5 }\end{array}$ & Preferentially postsynaptic & $\begin{array}{l}\uparrow P L C \\
\uparrow P K C \\
\uparrow P L A 2 \\
\uparrow \text { Calcium release } \\
\uparrow \text { Adenylate cyclase }\end{array}$ & $\begin{array}{l}\text { tADA } \\
\text { CHPG } \\
\text { DHPG } \\
\text { 3HPG } \\
S \text {-Sulfo-L-cysteine }\end{array}$ & $\begin{array}{l}\text { LY367385 } \\
\text { MCPG } \\
\text { AIDA } \\
\text { 4CPG } \\
\text { CPCCOEt } \\
\text { MPEP } \\
\text { SIB-1893 }\end{array}$ \\
\hline Group II & $\begin{array}{l}\text { mGluR2 } \\
\text { mGluR3 }\end{array}$ & Preferentially presynaptic & $\downarrow$ Adenylate cyclase & $\begin{array}{l}\text { DCG-IV } \\
\text { LY354740 } \\
\text { L-CCG-I } \\
\text { APDC }\end{array}$ & $\begin{array}{l}\text { LY341495 } \\
\text { MCCG } \\
\text { EGLU }\end{array}$ \\
\hline Group III & $\begin{array}{l}\text { mGluR4 } \\
\text { mGluR6 } \\
\text { mGluR7 } \\
\text { mGluR8 }\end{array}$ & Preferentially presynaptic & $\begin{array}{l}\downarrow \text { Adenylate cyclase } \\
\downarrow \text { cGMP-PDE }\end{array}$ & $\begin{array}{l}\text { L-AP4 } \\
\text { L-SOP } \\
\text { BzAPDC } \\
\text { Homo-AMPA }\end{array}$ & $\begin{array}{l}\text { CPPG } \\
\text { MAP4 } \\
\text { MSOP }\end{array}$ \\
\hline
\end{tabular}

3HPG = 2-amino-2-(3-hydroxyphenyl)acetic acid; 4CPG $=(S)$-4-carboxyphenylglycine; AIDA = 1-aminoindan-1,5-dicarboxylic acid; AMPA $=\alpha$-amino-3-hydroxy-5-methyl-4-isoxazolepropionic acid; APDC $=$ aminopyrrolidine-2,4-decarboxylate; APDC $=$ aminopyrrolidine dicarboxylate; cGMP = cyclic guanosine monophosphate; CHPG = 2-chloro-5-hydroxyphenylglycine; CPCCOEt $=7$-(hydroxyimino)cyclopropa $(b)$ chromen- $1 \alpha$-carboxylate ethyl ester; CPPG = cyclopropyl-4-phosphonophenylglycine; DCG-IV $=\left(2 S, 2^{\prime} R, 3^{\prime} R\right)-2-\left(2^{\prime}, 3^{\prime}\right.$-dicarboxycyclopropyl)glycine; DHPG $=(S)$-3,5-dihydroxyphenylglycine; EGLU $=2 S$ - $\alpha$-ethylglutamic acid; L-AP4 $=1$ - $(+)$-2-amino-4phosphonobutyrate; L-CCG-I $=\left(2 S, 1^{\prime} S, 2^{\prime} S\right)$-2-(carboxycyclopropyl)glycine; L-SOP = 1-serine- $O$-phosphate; LY341495 $=2$-amino -2-(2-carboxycycloprop-1-yl)-3-(xanth-9-yl)propanoic acid; LY354740 = 1S,2S,5R,6S-2-aminobicyclo[3.1.0]hexane-2,6-dicarboxylate monohydrate; LY367385 = (+)-2-methyl-4-carboxyphenylglycine; LY379268 = (-)-2-oxa-4-aminobicylco hexane-4,6-dicarboxylic acid; MAP4 = 2-amino-2-methyl-4-phosphonobutyrate; MCCG = 2-methyl-2-(2-carboxycyclopropyl)glycine; MCPG = $\alpha$-methyl-4-carboxyphenylglycine; mGluR = metabotropic glutamate receptor; MPEP = 2-methyl-6-(phenylethynyl)-pyridine; MSOP $=(\mathrm{R}, \mathrm{S})$-alpha-methylserine-O-phosphate; $\mathrm{PDE}=$ phosphodiesterase PKC = protein kinase $\mathrm{C} ; \mathrm{PLA} 2=$ phospholipase A2; PLC $=$ phospholipase $\mathrm{C} ; \mathrm{SIB}-1893=$ (/E/)-2-methyl-6-(2-phenylethenyl)pyridine; tADA = trans-azetidine-2,4-dicarboxylic acid.

to modulate multiple pathophysiological pathways may prove more effective than those directed at a single target. Neurons, astrocytes, microglia, oligodendrocytes, endothelial cells, and circulating immune cells all play roles in response to acute and subacute injury, as well as in chronic neurodegeneration. Thus, treatments that target multiple cell types and associated pathways may prove most beneficial.

This review examines the multipotential therapeutic utility of mGluR modulation in acute and chronic injury and neurodegeneration. Targeting mGluRs represents a multifunctional drug approach, in that they are expressed in a number of different cell types widely distributed throughout the CNS. ${ }^{12}$

\section{METABOTROPIC GLUTAMATE RECEPTOR-MEDIATED EFFECTS}

\section{Neurons}

Neurons express all three groups of mGluRs (Tables 2-4), depending on the location within the CNS. For example, neurons within the cortex and caudate-putamen express mGluR3 and mGluR5, but only mGluR3 is expressed in the septum. ${ }^{13}$ mGluR1 is predominantly expressed in the CA3 region of the hippocampus. ${ }^{14}$ After injury, the expression of mGluRs is altered. After kainate-induced seizures, for example, expression of
mGluR3 and mGluR5 in $\mathrm{NeuN}^{+}$neurons increases, ${ }^{13}$ and the expression of mGluR 1 and mGluR2/3 are also chronically increased in neurons after spinal cord injury. ${ }^{6}$

Stimulation of group I mGluRs increases neuronal excitability ${ }^{15}$ and has been linked to epileptic events. ${ }^{14}$ Antagonists for mGluR1 and mGluR5 and agonists for mGluR group II and III have anticonvulsant activities. In normal tissue, activation of mGluR1a in the hippocampus potentiates signaling, facilitating induction of longterm potentiation. ${ }^{14}$ Within neurons, group I mGluR receptors potentiate glutamatergic signaling. Addition of group I agonists, such as (S)-3,5-dihydroxyphenylglycine (DHPG), to neurons enhances the potency of NMDA-induced neuronal cell death. ${ }^{16-18}$ In addition, DHPG enhances the release of arachidonic acid in response to NMDA administration to neuronal cultures, increasing neuronal cell death ${ }^{18}$ via the production of superoxide and subsequent lipid peroxidation and DNA damage. ${ }^{19}$

Not surprisingly, antagonists of group I mGluRs are neuroprotective. For example, the mGluR1 antagonists AIDA, CPCCOEt, and LY367385 reduce neuronal cell death after mechanical trauma in vitro. ${ }^{20}$ Furthermore, MCPG, AIDA, and 4CPG are neuroprotective when neurons are subjected to oxygen and glucose deprivation in vitro. ${ }^{17}$ mGluR1 antagonists also limit cell death in response to the administration of $\mathrm{NMDA}^{21}$ or staurospor- 


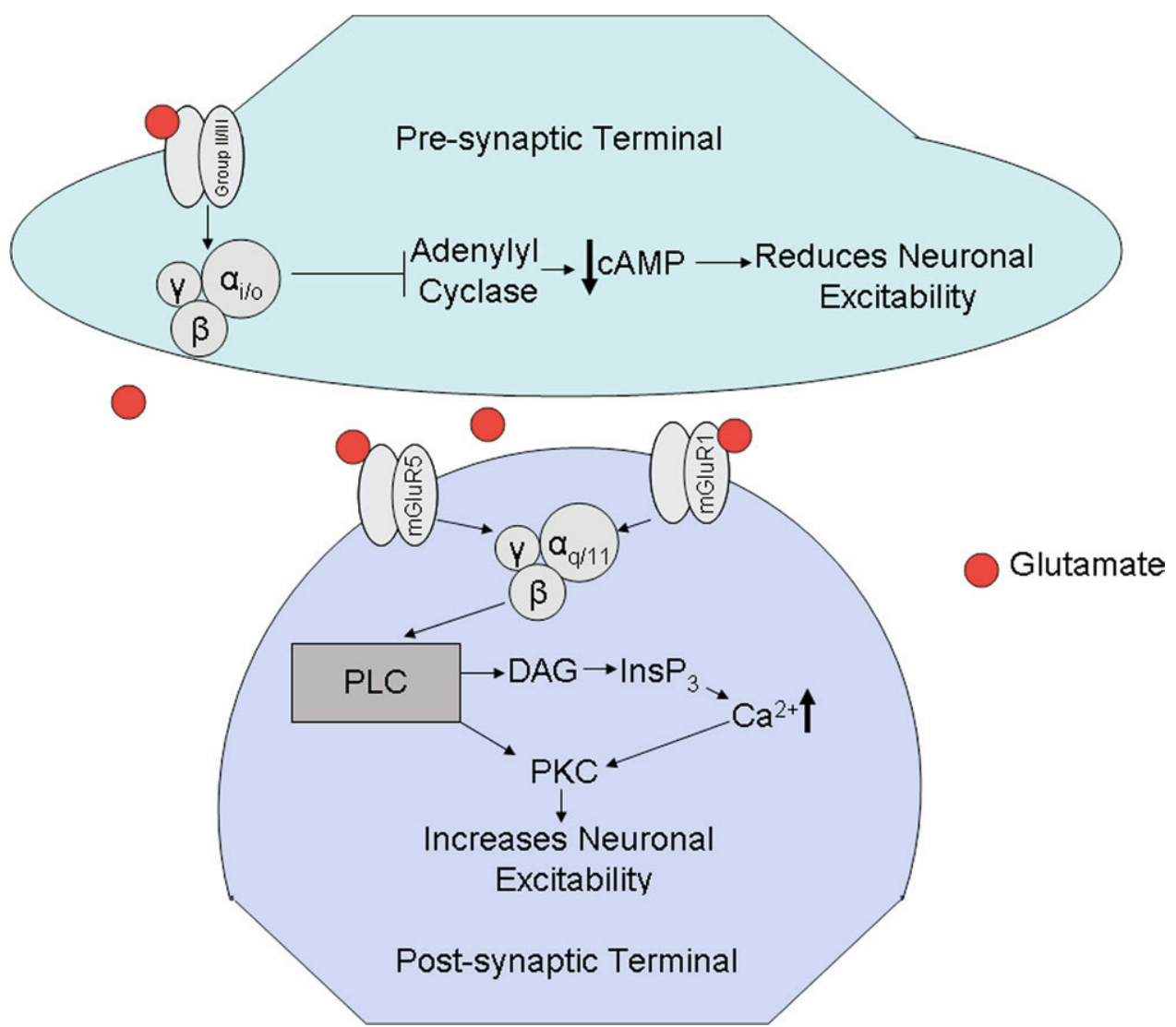

FIG. 1. Schematic of metabotropic glutamate receptor (mGluR) neuronal signaling. $\mathrm{DAG}=$ diacylglycerol; InsP $\mathrm{P}_{3}=\mathrm{inositol}_{1,4,5-}$ triphosphate; PKC = protein kinase C; PLC = phospholipase C.

ine. ${ }^{17}$ The mGluR5 antagonist MPEP also significantly reduced neuronal cell death in response to NMDA administration $^{22}$; however, these effects were found when MPEP was applied in a concentration that was effective in blocking NMDA channel openings. Thus, neuroprotective effects may not be a result of direct mGluR5 activity, but rather from noncompetitive NMDA antagonistic properties. Further work has shown that neuroprotective properties of mGluR5 antagonists are mediated by direct actions on NMDA receptors, and similar protective effects are observed in mGluR5 knockout mice. ${ }^{23}$

Administration of $\beta$-amyloid $(\mathrm{A} \beta)$ to cortical neuronal cultures causes neuronal apoptosis, which is exacerbated by application of the mGluR1 antagonist AIDA. ${ }^{24}$ In contrast, agonists of mGluR5 demonstrate neuroprotective properties. For example, the nonselective mGluR group I agonist DHPG or the selective mGluR5 agonist CHPG are neuroprotective when neurons are challenged

Table 2. Cells Expressing Group I mGluR

\begin{tabular}{|c|c|c|}
\hline Cell Type & Receptor Subtype & Function \\
\hline Neuron & mGluR1; mGluR5 & Postsynaptic; operates through PLC activation and potentiation \\
\hline \multirow{2}{*}{ Astrocyte } & mGluR1 ${ }^{36} ;$ mGluR5 $5^{6,36}$ & Elevates intracellular calcium ${ }^{94}$ \\
\hline & & $\begin{array}{l}\text { May contribute to neuronal death by increasing glutamate } \\
\text { release }\end{array}$ \\
\hline T lymphocyte & mGluR1; mGluR5 $5^{72}$ & mGluR5 reduces activation in a cAMP dependent fashion ${ }^{72}$ \\
\hline B lymphocyte & mGluR1; mGluR5 $5^{95}$ & Unknown \\
\hline Microglia & mGluR5 ${ }^{12,36}$ & $\begin{array}{l}\text { Attenuates activation (proliferation, production of } \\
\text { inflammatory mediators) }\end{array}$ \\
\hline Hepatocytes & mGluR5 $5^{96}$ & May contribute to oxidative induced cell death \\
\hline Pinealocytes & mGluR5 $^{93}$ & Unknown \\
\hline Melanocytes & mGluR1 $^{97} ;$ mGluR5 ${ }^{98}$ & Induces Proliferation \\
\hline Oligodendrocytes & ${\text { mGluR } 5^{94}}^{4}$ & Reduces oxidative stress ${ }^{69}$ \\
\hline Endothelial cells & mGluR1; mGluR5 ${ }^{100}$ & $\begin{array}{l}\text { May limit cell death }{ }^{99} \\
\text { Increase permeability }\end{array}$ \\
\hline
\end{tabular}


Table 3. Cells Expressing Group II mGluR

\begin{tabular}{|c|c|c|}
\hline Cell Type & Receptor Subtype & Function \\
\hline Neuron & mGluR2; mGluR3 $3^{91}$ & $\begin{array}{l}\text { Reduces adenylate cyclase activity, reducing cAMP and neuronal } \\
\text { excitability. mGluR2 may be less neuroprotective than } \\
\text { mGluR } 3^{91}\end{array}$ \\
\hline Astrocyte & mGluR3 $3^{12}$ & Increases growth factor production ${ }^{92}$ \\
\hline Microglia & mGluR2; mGluR3 ${ }^{41}$ & $\begin{array}{l}\text { mGluR2 stimulates a neurotoxic phenotype, while mGluR3 is } \\
\text { neuroprotective }\end{array}$ \\
\hline Pinealocytes & mGluR3 ${ }^{93}$ & Negatively regulate melatonin secretion \\
\hline Oligodendrocytes & mGluR3 $39,94,99$ & May play a role in cell survival ${ }^{99}$ \\
\hline
\end{tabular}

with nitric oxide (NO), ${ }^{25} \mathrm{~A} \beta,{ }^{26}$ or platelet activating factor. ${ }^{27}$ More specifically, mGluR5 agonists block apoptotic neuronal cell death, ${ }^{17}$ and these effects are reversed by the mGluR5 antagonist MPEP. ${ }^{26}$

Group II and III mGluRs are presynaptic receptors on neurons that act to reduce glutamatergic signaling. As such, excitotoxicity may be reduced after trauma. A number of studies have shown neuroprotective activities of group II and group III mGluR agonists. For example, activation of these receptors with APDC, L-CCG-I, LY379268, or L-AP4 increases neuronal survival in response to several different challenges, including activation of endonucleases with NO donors, ${ }^{25,28,29}$ platelet activating factor, ${ }^{27}$ or NMDA challenge. ${ }^{30}$ Electrophysiological function is also improved with group III agonist treatment after oxygen and glucose deprivation. ${ }^{31}$ In neuronal and astrocyte mixed cultures, administration of DCG-IV, APDC, or L-CCG-I, group II mGluR agonists, or the group III mGluR agonists L-SOP or L-AP4 reduced $\mathrm{A} \beta$-induced neuronal apoptosis. ${ }^{32}$

The group II mGluR agonists LY379268, DCG-IV, APDC, and LY354740 reduced neuronal release of lactate dehydrogenase after mechanical trauma in vitro. ${ }^{33,34}$ These effects may have been specific to mGluR2, because administration of the mGluR2/3 antagonist EGLU reduced the observed neuroprotection but the mGluR3 antagonist $\beta$-acetyl-aspartyl-glutamate $(\beta$-NAAG) did not. ${ }^{33}$ Furthermore, the mGluR3-specific agonist $\alpha$ NAAG did not have the neuroprotective effects observed by LY379268, the nonspecific group II agonist.
Two specific agonists of group III mGluRs, L-SOP and L-AP4, also significantly reduced neuronal cell death after mechanical injury in vitro. ${ }^{35}$ These neuroprotective effects were mediated by a reduction in cAMP, and antagonists of group III mGluRs exacerbated neuronal death.

\section{Microglia}

Metabotropic glutamate receptors are expressed in glial cells, where their activation exerts numerous effects that are crucial for glial cell function and glial-neuronal interaction under physiologic and pathologic conditions. mGluR5 mRNA has been detected in cultured microglia, ${ }^{36}$ but has not been found in resident microglia of intact brain by in situ hybridization. ${ }^{13}$ Although mGluR1 mRNA has not been detected in cultured microglia, ${ }^{36}$ in humans mGluR $1 \alpha$ immunoreactivity is colocalized with a subset of cells of microglia-macrophage lineage in multiple sclerosis lesions. ${ }^{37}$ Recently, however, using immunocytochemistry and Western blotting, we found that mGluR5 protein is expressed in microglia cultured from rat brain, ${ }^{38}$ whereas mGluR $1 \alpha$ is negligibly expressed (FIG. 2). Double-labeling with the microglial markers OX42 and ED1 showed that microglial cells do express mGluR5 (FIG. 3C).

Preliminary experiments in which the group I mGluR agonist DHPG is applied to microglia stimulated with lipopolysaccharide demonstrate that DHPG has an inhibitory effect on microglial activation. Measures of microglial activation including NO production (FIG. 3A) and proliferation (FIG. 3B) were significantly reduced by the pretreatment of purified cortical microglia (96\% pure)

Table 4. Cells Expressing Group III mGluR

\begin{tabular}{|c|c|c|}
\hline Cell Type & Receptor Subtype & Function \\
\hline Neuron & mGluR4; mGluR6; mGluR7; mGluR8 & $\begin{array}{l}\text { Reduces Adenylate cyclase activity, reducing } \\
\text { cAMP and neuronal excitability }\end{array}$ \\
\hline Astrocyte & mGluR4 ${ }^{42}$; mGluR6; mGluR7; mGluR8 36 & $\begin{array}{l}\text { Increases glutamate uptake, potentially providing } \\
\text { neuroprotection }{ }^{101}\end{array}$ \\
\hline Microglia & mGluR4; mGluR6; mGluR8 ${ }^{12,41}$ & Stimulates a neuroprotective phenotype ${ }^{40,41}$ \\
\hline Osteoblasts & mGluR4; mGluR8 ${ }^{102}$ & May play a role in proliferation ${ }^{102}$ \\
\hline Bone marrow stromal cells & mGluR4; mGluR8 ${ }^{103}$ & Reduces nitric oxide synthase activity ${ }^{103}$ \\
\hline Endothelial cells & mGluR4 $4^{100}$ & Increase permeability ${ }^{100}$ \\
\hline
\end{tabular}



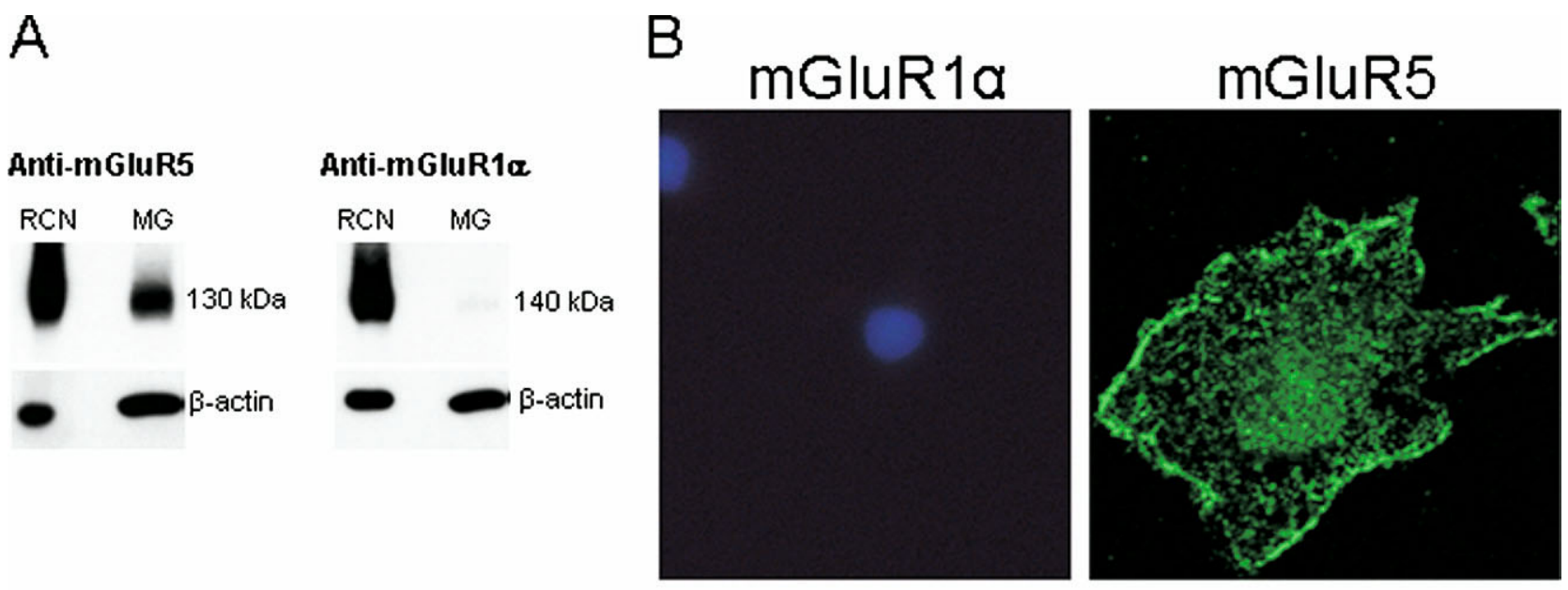

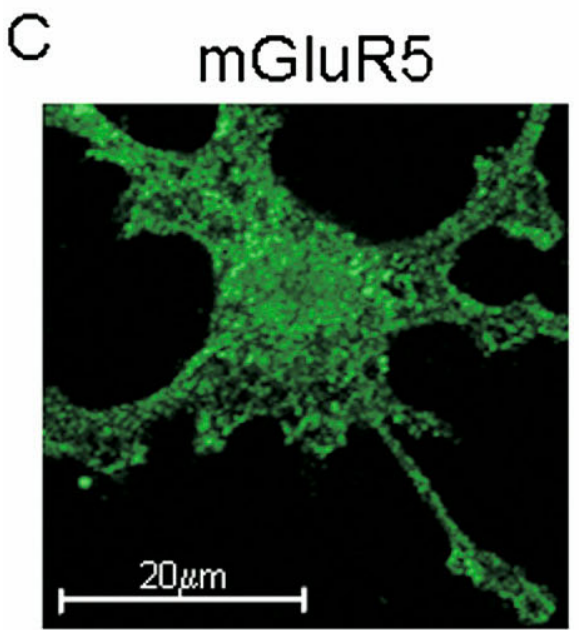

mGluR5

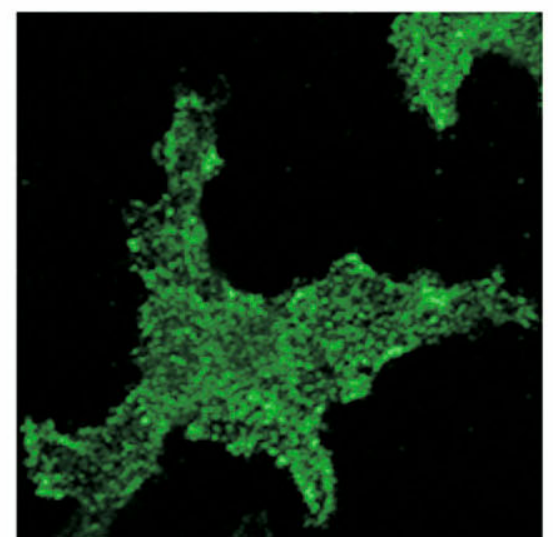

OX42

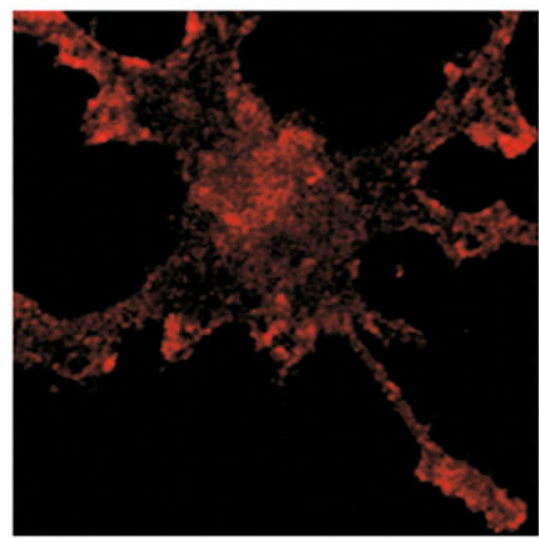

ED1

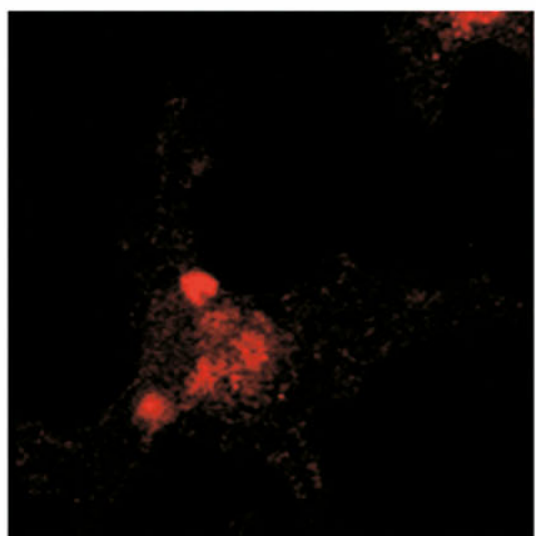

Merged

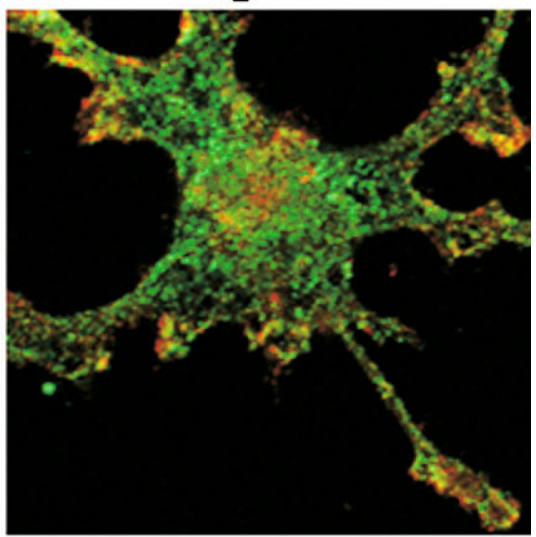

Merged

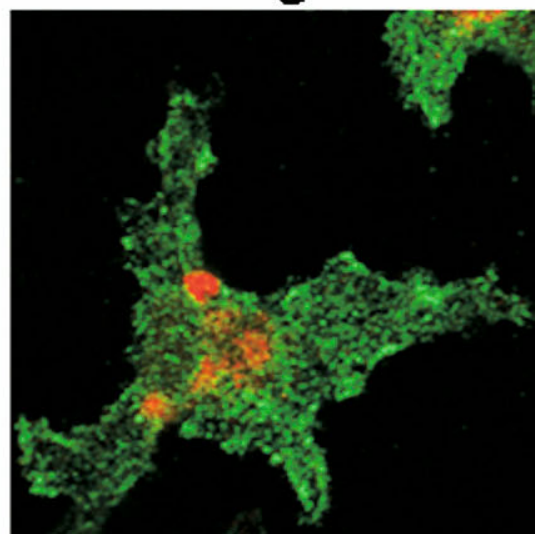

FIG. 2. Microglia express the group I mGluR receptors: mGluR5 and mGluR $1 \alpha$, as demonstrated by Western blot (A) and immunocytochemistry $(B, C)$. Rat cortical neuron $(R C N)$ samples were run alongside microglia (MG) as positive controls for the antibodies. To confirm microglial expression of mGluR5, cells were double-labeled with common markers for microglia, including OX42 and ED1 (C). Cell nuclei are stained with $4^{\prime}, 6$-diamidino-2-phenylindole DAPI (blue). Reproduced with permission from Byrnes et al. ${ }^{38}$

with DHPG and the mGluR1 antagonist CPCCOEt prior to lipopolysaccharide stimulation. Furthermore, the mGluR5-specific agonist CHPG showed similar actions, suppressing NO, reactive oxygen species production, proliferation, and neurotoxicity. ${ }^{38}$ These effects were not observed in microglial cultures from mGluR5 knockout mice. ${ }^{38}$ Suppression of microglial activation by mGluR5 agonists is mediated by the $\mathrm{G} \alpha_{\mathrm{q}}$ signal transduction pathway, and requires activation of PLC, PKC, and calcium release. $^{38}$ 


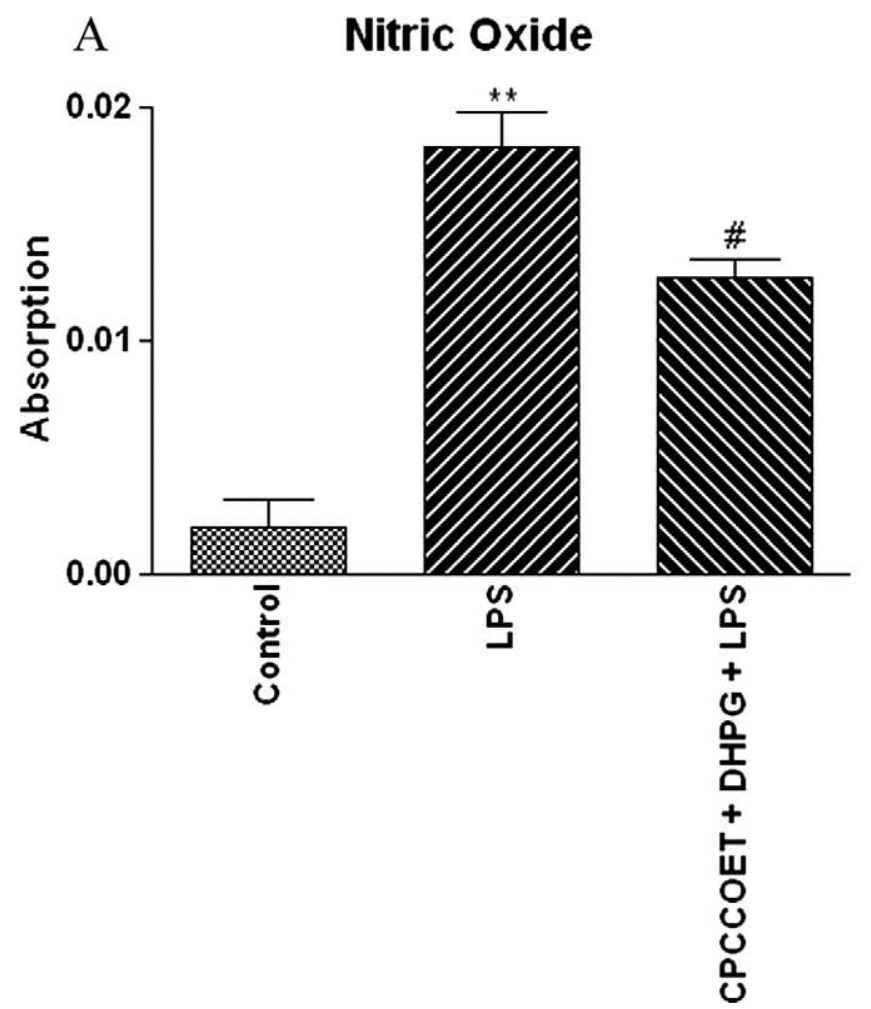

B Proliferation

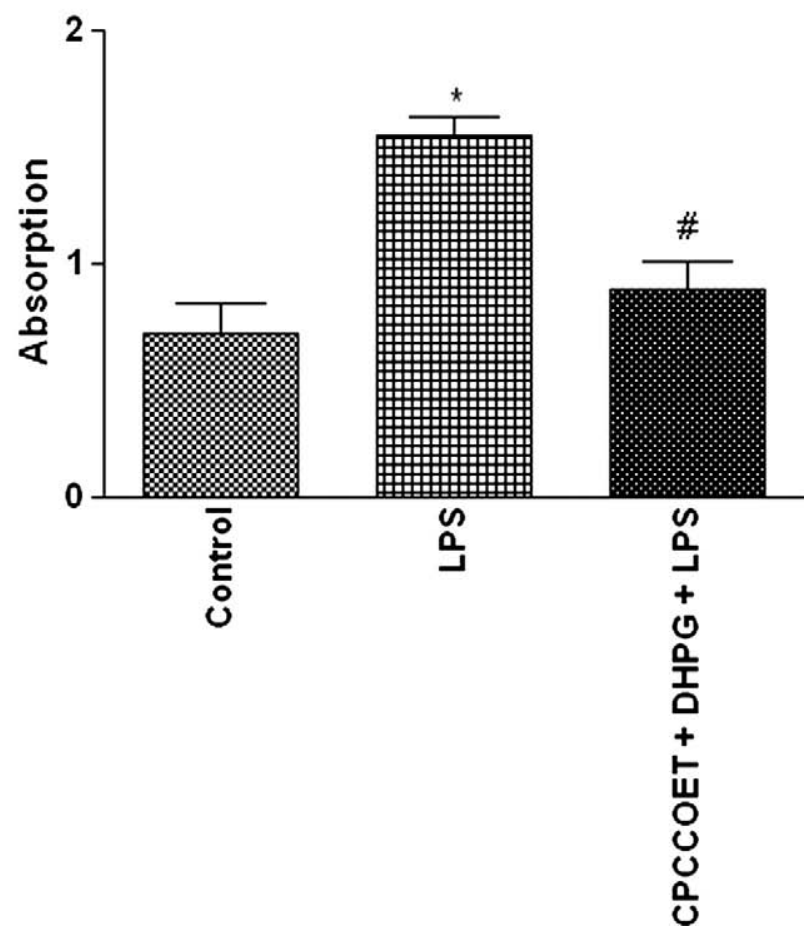

FIG. 3. Stimulation of mGluR5 with DHPG (mGluR1 is inhibited by the addition of CPCCOET) reduces lipopolysaccharide (LPS)-induced activation of microglia. Microglial activation was measured by NO production (a) and proliferation (b) at $24 \mathrm{~h}$ after stimulation. Both measurements were significantly inhibited by pretreatment with DHPG + CPCCOET. Error bars indicate standard error of the mean $( \pm$ $\mathrm{SEM}) .{ }^{* *} p<0.01$ vs. control; $\# p<0.05$ vs. LPS. For abbreviations, see abbreviation list.

Cultured microglia express mRNA and protein for the group II mGluRs, mGluR2 and mGluR3 $3{ }^{39}$ Activation of mGluR2 and mGluR3 by selective agonists DCG-IV and L-CCG-I promotes a neurotoxic microglial phenotype. In addition, chromogranin $\mathrm{A}$ (CGA)-induced and $\mathrm{A} \beta$ $\left(\mathrm{A} \beta_{25-35}\right)$-induced microglial activation is modulated by group II mGluRs, because inhibition by the antagonist MCCG reduced toxin-induced microglial reactivity and related neurotoxicity. ${ }^{39}$ More recently, activation of microglial mGluR2 was shown to exacerbate cell death, whereas activation of mGluR3 was protective in a model of myelin-induced microglial neurotoxicity. ${ }^{40}$ Although mGluR3 mRNA has not been found in microglia from intact rat brain, ${ }^{13}$ mGluR2/3 immunoreactivity has been observed in microglia and macrophage-like cells in autopsy brain samples from patients with multiple sclerosis. ${ }^{37}$

Microglia also express mRNA and protein for the group III mGluRs mGluR4, mGluR6, and mGluR8 - but not mGluR7. ${ }^{41}$ Activation of these receptors with the specific group III agonists L-AP4 or RS-PPG inhibited forskolin-induced cAMP production, linking them to the negative inhibition of adenylate cyclase. Agonists of group III mGluRs reduced microglial activation when stimulated with lipopolysaccharide, CGA, or $\mathrm{A} \beta_{25-35}$, and agonist treatment reduced their neurotoxicity after microglial stimulation with lipopolysaccharide or CGA; thus, activation of group III mGluRs can protect neurons against microglial-mediated neurotoxicity. ${ }^{41}$

The protective effects of group III mGluR activation has been confirmed in a model of myelin-induced microglial neurotoxicity, ${ }^{40}$ findings that may have important implications for the treatment of multiple sclerosis. Notably, analysis of human tissue samples revealed that mGluR8, but not mGluR4, was expressed in multiple sclerosis lesions, in particular in cells of the microgliamacrophage lineage with an amoeboid morphology. ${ }^{42}$ With respect to lesion stage, it was found that the mGluR8 expression was strongly colocalized to actively demyelinating lesions.

\section{Astrocytes}

mGluR5 receptor mRNA has been detected in astrocytes isolated from young rats ${ }^{43}$ and from adult rats. ${ }^{44}$ The expression profile of mGluR5 in astrocytes appears to decrease during development, ${ }^{44}$ but in the intact brain immunohistochemistry reveals mGluR5 protein expression. ${ }^{45}$ The other group I mGluR, however, mGluR1, shows limited astrocytic expression. mGluR1a receptor mRNA or protein has not been detected in cultured cortical astrocytes grown in conventional medium or astrocyte-defined media. ${ }^{46-48}$ In a small proportion (10\%) of cultured astrocytes prepared from the spinal cord, how- 
ever, mGluR1a receptors have been detected by immunohistochemistry. ${ }^{49}$ These data are consistent with observations of human spinal cord from patients with amyotrophic lateral sclerosis. ${ }^{50}$

The expression of mGluR5 receptors is modulated by extracellular signals. Cultured astrocytes grown in conventional serum-containing medium show low expression, whereas expression is upregulated when cells are cultured in medium containing growth factors such as basic fibroblast growth factor, epidermal growth factor, or transforming growth factor- $\alpha$ (TGF- $\alpha$ ). ${ }^{46,48}$ It has been suggested that the expression profile induced by the growth medium mimics the activation of astrocytes during reactive gliosis. Accordingly, immunohistochemical analysis revealed mGluR5 expression in reactive astrocytes surrounding a lesion site or induced by epileptic seizures to be higher than in nonactivated astrocytes. ${ }^{6,51-53}$ In humans, mGluR5 receptors have been found to be diffusely upregulated in reactive astrocytes under pathological conditions, such as multiple sclerosis $^{37}$ and amyotrophic lateral sclerosis. ${ }^{50}$

Activation of mGluR5 in astrocytes stimulates polyphosphoinositide (PI) hydrolysis ${ }^{48}$ and generates oscillatory increases in intracellular calcium. ${ }^{36,54}$ This results in the release of transmitters such as glutamate, which in turn modulates neuronal excitability and promotes synchronized activation of groups of neurons. ${ }^{55}$ Activation of group I receptors by DHPG stimulates MAP kinase pathways ${ }^{56}$ and selective activation of mGluR5 stimulates phospholipase D signaling in cultured cortical and hippocampal astrocytes. ${ }^{57}$

Among group II mGluRs, astrocytes express mGluR3 receptors in vitro and in vivo, whereas mGluR2 receptors are not expressed. ${ }^{13,58,59}$ mGluR3 mRNA is expressed in cultured astrocytes, ${ }^{36}$ but detection of mGluR3 protein has been unsuccessful with the current battery of mGluR3-specific antibodies. ${ }^{60,61}$ Similar to mGluR5 expression, mGluR3 expression is upregulated in media containing growth factors in cultured astrocytes. ${ }^{60}$

mGluR2 and mGluR 3 receptors are negatively coupled to adenylate cyclase, and activation of group II mGluRs by the selective agonist LY379268 reduces forskolinstimulated cAMP formation in the absence of extracellular calcium but enhances cAMP formation in the presence of calcium. ${ }^{62}$ This dual regulation of cAMP formation is unique to cultured astrocytes. In addition, activation of group II mGluRs amplifies the stimulation of cAMP formation mediated by $\beta 2$-adrenergic receptors, leading to adenosine release in cultured astrocytes. ${ }^{63}$ Activation of mGluR2/3 receptors also stimulates the MAP-ERK kinase and PI-3-kinase signaling pathways. ${ }^{60,64}$ Stimulation of MAP kinase and PI-3-kinase pathways increases formation of TGF- $\beta$, which is neuroprotective, ${ }^{65}$ and also protects against astrocytic damage caused by oxygen and glucose deprivation in culture. $^{66}$

The expression of mGluR4 in astrocytes is controversial; some studies have detected the receptor in primary cultures of rat and mouse cortical astrocytes by RT-PCR and Western immunoblotting, ${ }^{67}$ whereas others have not. $^{36,61}$ Neither mGluR6 nor mGluR7 expression has been detected in cultured astrocytes to date. ${ }^{61}$ Although mGluR8 mRNA is not expressed in cortical astrocytes grown in conventional medium, it is upregulated in astrocytes grown in astrocyte-defined media. In humans, mGluR4 receptors are not found in resting astrocytes, but are detectable in reactive astrocytes of multiple sclerosis lesions. $^{42}$

\section{Other cell types}

Studies have shown that mGluRs are expressed on a number of other CNS and peripheral cell types, including oligodendrocytes, lymphocytes, meningeal cells, pinealocytes, hepatocytes, osteoblasts, bone marrow cells, and pancreatic islet cells (for review, see Ferraguti and Shigemoto ${ }^{12}$ and Maiese et al. ${ }^{68}$ ). Cultured oligodendrocytes prepared from neonatal rats express mGluR $1 \alpha$, mGluR2/3, mGluR4, and mGluR5 receptors. Expression of these receptor subtypes is developmentally regulated and is high in early and late oligodendrocyte precursors, and low or absent in immature and mature oligodendrocytes. ${ }^{69}$ Rat O4- and O1-positive precursors and A2B5positive early precursors from adult human brain express both mGlu3 and mGlu5 receptor proteins. ${ }^{70,71}$ In oligodendrocytes, group I mGluR agonists reduce oxidative stress and excitotoxic cell death in a PKC $\alpha$-mediated manner. ${ }^{69}$ This effect is reversed by the mGluR5 antagonist MPEP, suggesting that mGluR5 mediates the protective effect.

Both T and B lymphocytes express group I, II, and III mGluRs. ${ }^{72,73}$ In $\mathrm{T}$ cells, mGluR5 activation results in cAMP upregulation and an inhibition of T-cell activity. ${ }^{72}$ Activation of mGluR1 in T cells resulted in increases in ERK1/2 phosphorylation and cell proliferation. ${ }^{72}$ Activation of group III mGluRs with L-AP4 has been shown to increase levels of reactive oxygen species in lymphocytes and contribute to neuronal toxicity, which is contrary to its effects in vivo. ${ }^{73}$

\section{THERAPEUTIC EFFECTS}

\section{mGluR1 antagonists}

As has been discussed here, mGluR1 receptors are expressed on a number of cells within the CNS, including neurons, meningeal cells, microglia, astrocytes, $\mathrm{T}$ cells, and B cells (Table 2). Through interactions with the Homer proteins, group I mGluRs may also have effects on NMDA signaling, ${ }^{74}$ and they potentiate NMDA-mediated neurotoxicity and increase arachidonic 
acid release. ${ }^{18}$ Furthermore, mGluR1 agonists increase T-cell proliferation and activation of the MAP kinase signal transduction cascade, increasing inflammation. ${ }^{72}$ Therefore, antagonists of mGluR1 may have multimodal therapeutic effects after CNS trauma.

Inhibition of mGluR1 receptors has beneficial effects after CNS damage. After spinal cord contusion injury, injections of the mGluR group I antagonist AIDA into the lesion site improved early locomotor recovery, as measured by standardized Basso-Beattie-Bresnahan (BBB) scores. ${ }^{75}$ However, differences between animals receiving AIDA or vehicle disappeared by 28 days post injury, possibly because only single-dose administration was delivered. Beneficial effects were mediated by the mGluR $1 \alpha$ receptor, in that the effects were also found with the mGluR $1 \alpha$-specific antagonist LY367385, but not the mGluR5-specific antagonist MPEP. Treatment with the mGluR $1 \alpha$ antagonist also produced white and gray matter sparing; however, the cellular target of this effect was not investigated.

mGluR1 antagonists have also proved protective in traumatic brain injury models (FIG. 4). AIDA administration after lateral fluid percussion in rats significantly improved neuroscores and MRI-based lesion volume, ${ }^{20}$ as well as reducing overall neuronal cell death. ${ }^{76}$ Furthermore, the mGluR1 antagonist YM-202074 is neuroprotective after cerebral ischemia. ${ }^{77}$ After middle cerebral artery occlusion in rats, YM-202074 administration within $2 \mathrm{~h}$ of the onset of ischemia significantly reduced infarct volumes in the brain and improved neurological scores.

\section{mGluR5 agonists}

mGluR5 can operate through either release of calcium from intracellular stores, similar to mGluR1, or it can activate the Src family of tyrosine kinases, producing intracellular signaling through the ERK/MAPK cascade. ${ }^{78}$ As already discussed, expression of mGluR5 is found in a number of CNS and peripheral cells (Table 2), ${ }^{12}$ and its actions in different cells have suggested strong possibilities for therapeutic potential. For example, mGluR5 agonists have shown antiapoptotic properties in neuronal cultures, ${ }^{17,25-27}$ and have strong anti-inflammatory effects in microglial cultures. ${ }^{38}$ In addition, group I mGluRs can activate PKC (FIG. 1), which can cause upregulation of inward rectifier potassium channels and reduce microglial activation. ${ }^{79}$ mGluR5 activation also reduces excitotoxic death in oligodendrocyte cultures. ${ }^{69}$ Cocultures of neurons and astrocytes suggested the requirement of astrocytes for a CHPG-mediated excitotoxicity. ${ }^{80}$ In this coculture system, administration of the mGluR5 agonist CHPG significantly reduced NMDAmediated currents after a stretch-injury; without astrocytes, CHPG did not modulate the NMDA responses.
However, this study did not directly address the effects of CHPG on astrocytic cultures.

Although a number of reports indicate that treatment with the specific mGluR5 agonist CHPG is neuroprotective in vitro and in vivo, treatment with the mGluR5 antagonist MPEP may also provide neuroprotection. The fact that the group I receptors mGluR1 and mGluR5 have similar signaling pathways and intracellular effects led to the theory that inhibition of mGluR5, similar to mGluR1, would be neuroprotective. Indeed, administration of MPEP significantly reduced neuronal death after glutamate or NMDA exposure. ${ }^{22}$

Nonetheless, the confusing actions of mGluR5 agonismantagonism is underscored in a 2001 study by Bao et al., ${ }^{81}$ in which CHPG or MPEP was administered after middle cerebral artery occlusion-induced focal ischemia. Both the agonist CHPG and antagonist MPEP reduced infarct volume when applied at $250 \mathrm{nmol}$ concentrations. Application of MPEP after injection of 6-hydroxydopamine into the substantia nigra also attenuated neuronal loss. ${ }^{82}$

Preliminary studies in our laboratory have shown promising beneficial effects of mGluR5 agonists in a rat spinal cord contusion model and in a mouse traumatic brain injury model. Intrathecal administration of CHPG for 7 days after a moderately severe spinal cord contusion at $\mathrm{T} 9$ resulted in a significant improvement in function, as measured by the BBB score at 28 days post injury (FIG. 5).

This apparent confusion regarding mGluR5 agonists and antagonists was resolved by work of Lea et al., ${ }^{23}$ which definitively showed that neuroprotective actions of the mGluR5 antagonists MPEP or MTEP do not reflect actions at the mGluR5 receptor. Instead, MPEP acts to directly inhibit NMDA receptor signaling, and application of the antagonists in cultures lacking the mGluR5 receptors (mGluR5 knockouts) yields the same neuroprotective effects as in cultures from wild-type animals.

\section{Group II and III mGluR agonists}

Group II and III mGluRs are presynaptic receptors on neurons, ${ }^{30}$ but are also expressed on microglia, astrocytes, and a number of other cell types (Tables 3 and 4). Activation of these receptors reduces glutamate release and GABAergic transmission in neurons, ${ }^{83}$ thus potentially reducing excitotoxic cell death. Furthermore, group III mGluR activation induces neuroprotective phenotypes in microglia, ${ }^{40,41}$ although nonspecific activation of the group II mGluR2/3 has shown neurotoxic effects $^{39}$, whereas the group II agonist DCG-IV induces brain-derived neurotrophic factor (BDNF) expression in microglia. ${ }^{84,85}$ In astrocytes, activation of mGluR $2 / 3$ induces the release of neuroprotective TGF- $\beta{ }^{65}$ These findings suggest that group II and III mGluR agonists may also have multipotential therapeutic actions. 


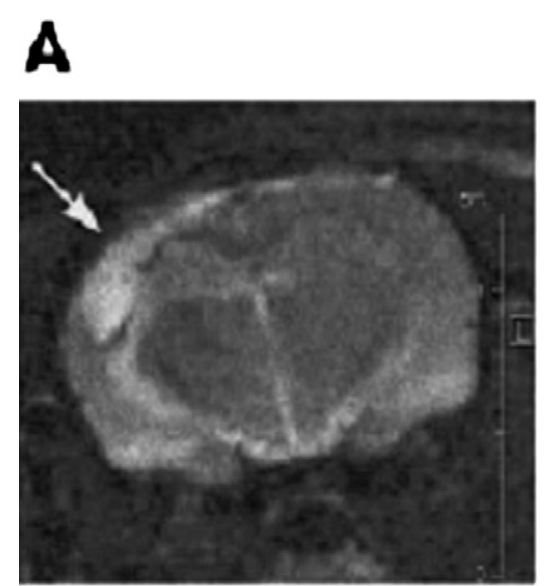

Control

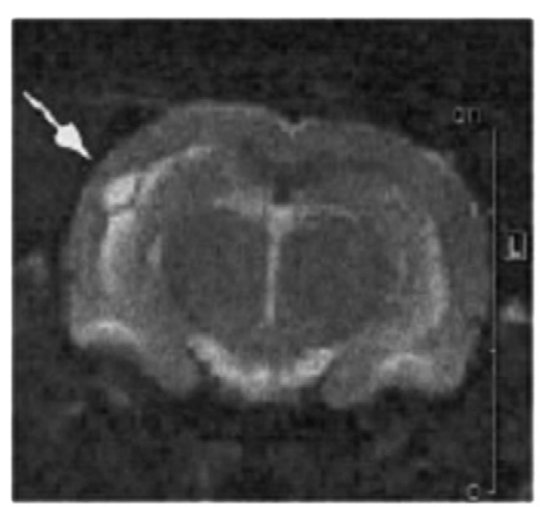

AIDA

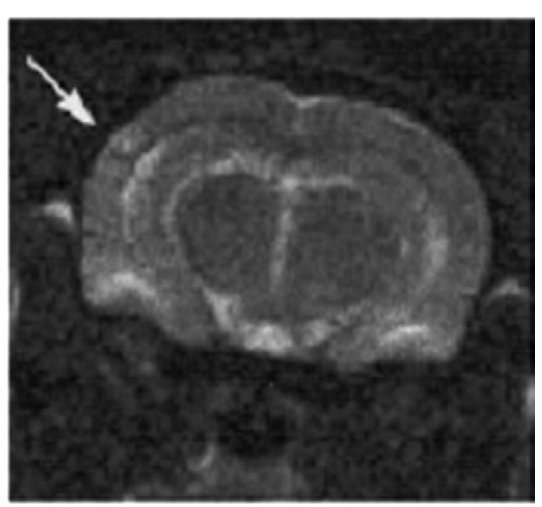

MCPG

B

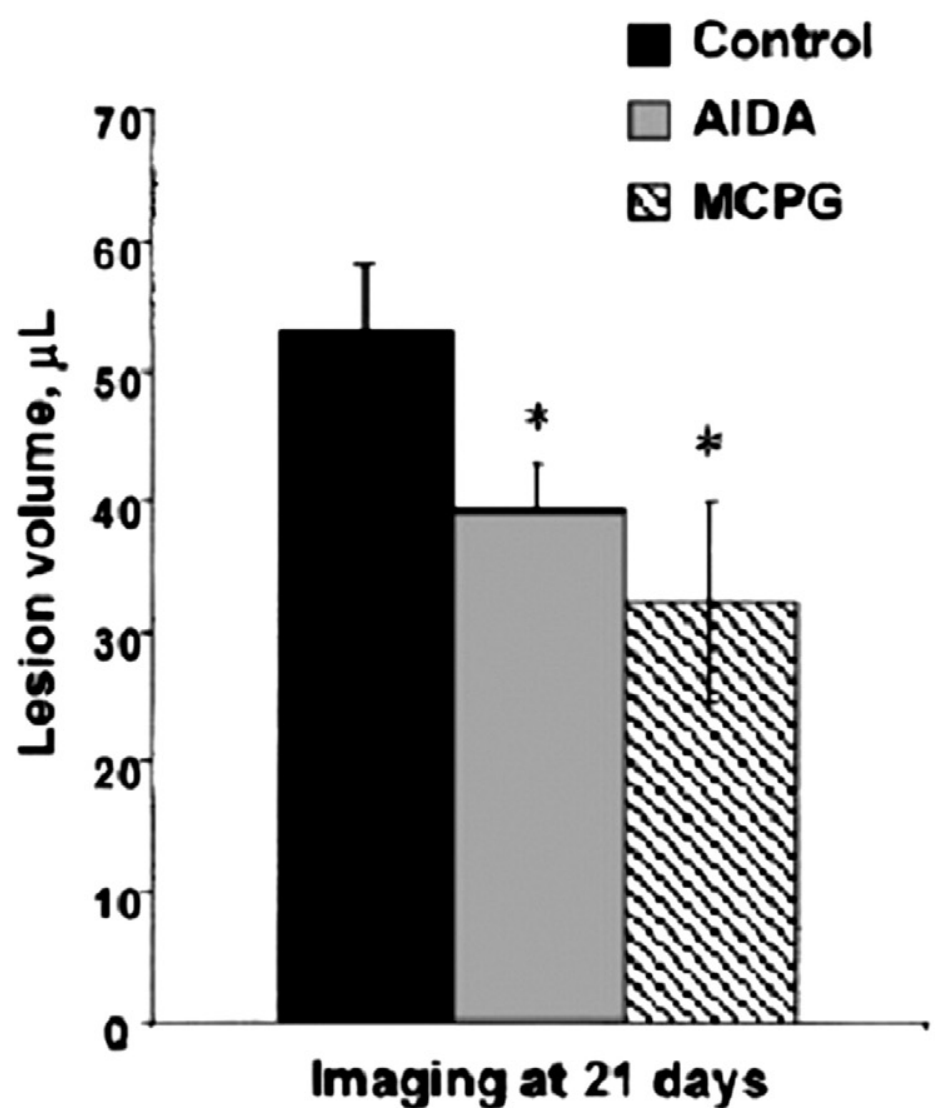

FIG. 4. AIDA- and MCPG-treated animals developed significantly smaller lesions after traumatic brain injury (TBI) than vehicle-treated control animals. (A) Representative T2-weighted magnetic resonance images of control and mGluR1 antagonist-treated rat brains at day 21 after TBI. (B) Summary of the effects of AIDA and MCPG treatments on lesion volume after TBI. The histograms represent average lesion volume $(\mu \mathrm{L})$ at day 21 after injury ( \pm SEM), as measured using T2-weighted MRI. $n=9$ to 11 animals per treatment. ${ }^{*} p<0.05$ versus vehicle-treated controls using one-tailed $t$ test. Reproduced with permission from Faden et al. ${ }^{20}$ For abbreviations, see abbreviation list.

In vivo, the group II agonist LY379268 reduced neuronal loss in the hippocampus after global ischemia in a gerbil model and application of LY379268 up to $2 \mathrm{~h}$ after occlusion was neuroprotective in a rat model of focal ischemia. ${ }^{30}$ These effects may reflect not only reduced neuronal death directly, but also the role of stimulating astrocytes in producing neuroprotective factors ${ }^{65}$ and reducing glutamate release. ${ }^{30}$

In other models of CNS damage, such as spinal cord injury, traumatic brain injury, or excitotoxic injections, group II and III mGluRs provide neuroprotection. For example, after spinal cord injury, group II and III mGluR 


\section{Day BBB Score}

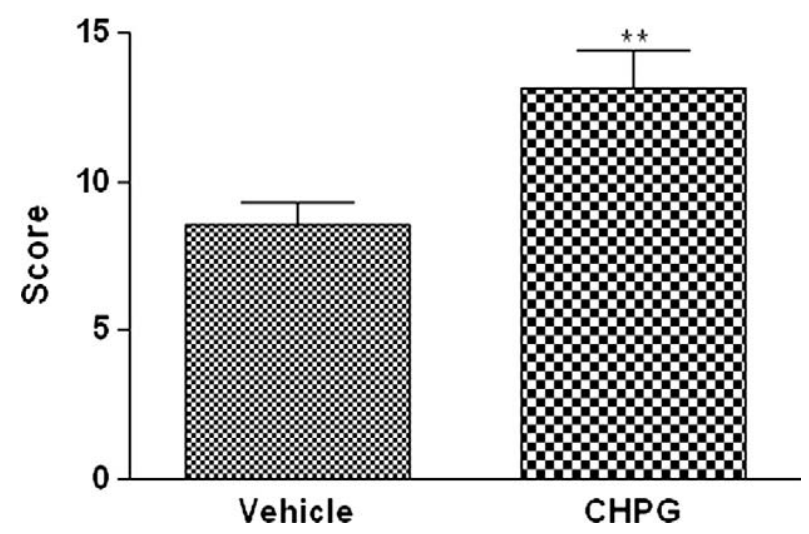

FIG. 5. Hindlimb locomotor function was assessed at day 28 after spinal cord injury in rats. CHPG treatment resulted in a significant improvement in Basso-Beattie-Bresnahan (BBB) score. Error bars indicate $\pm \mathrm{SEM} ;{ }^{* *} p<0.01$. For abbreviations, see abbreviation list.

agonists improve some measures of recovery, such as reduced allodynia. ${ }^{86}$ Additionally, administration of the mGluR4 agonist $(R, S)$-phosphonophenylglycine (RSPPG) reduces NMDA-induced neuronal death. ${ }^{87}$ That these results are due to actions at the mGluR4 receptor is indicated by control experiments in mGluR4 knockout mice, which showed no neuroprotection with the addition of RS-PPG after NMDA administration. Administration of LY379268 30 minutes after controlled cortical impact injury in mice resulted in significant improvements in both motor and cognitive function (FIG. 6). ${ }^{33}$ Similarly, treatment with LY354740 significantly improved neurological scores at 2 weeks post injury after lateral fluid percussion injury in rats. ${ }^{34}$ Furthermore, blocking the breakdown of the endogenous mGluR2/3 neurotransmitter NAAG with ZJ-43 resulted in significant reductions in neuronal death and excitotoxicity. ${ }^{88}$

\section{FUTURE WORK}

To date, neurons have been the assumed target of mGluR agonists and antagonists in vivo. A number of other cells express functional mGluRs, however, which may play pathophysiological or protective roles after CNS injury. Therefore, more research remains to be done on the function of mGluRs in the various cell types and their specific roles in vivo. Conditional knockout models may help to discriminate specific cell contributions to neuroprotection and recovery.

In addition, because acute and chronic CNS disorders share similar mechanisms of neuronal death, including inflammation and neuronal apoptosis, mGluRs may also provide therapeutic targets for chronic neurodegenerative disorders. For example, mGluR1 is strongly expressed in the substantia nigra, ${ }^{12}$ and group I mGluRs facilitate inhibitory signaling in the striatal pathways. ${ }^{74}$
Antagonists against mGluR1, such as LY367385, attenuate the loss of dopamine and tyrosine hydroxylasepositive neurons after injection of 6-hydroxydopamine into the substantia nigra. ${ }^{82}$ mGluR 1 is also expressed in the hippocampus, ${ }^{12}$ and inhibition of mGluR1 signaling may be beneficial in Alzheimer's disease. ${ }^{89}$ Group II and III agonists also reduce GABAergic and glutamatergic transmission in the basal ganglia, and improve motor activity in experimental models of Parkinson's disease (for review, see Maiese et al. ${ }^{68}$ Benarroch,${ }^{74}$ and Rouse et al. ${ }^{90}$ ). The group II agonist LY354740 reduces muscle rigidity and catalepsy in an animal model of Parkinson's disease. $^{91}$

\section{CONCLUSION}

Although mGluRs are less frequently investigated than neuronal expression, it is clear that they are expressed on a number of different cell types. Group I, II, and III mGluRs are found on cell types within, and peripheral to, the CNS, including neurons, microglia, astrocytes, oligodendrocytes, $\mathrm{T}$ and $\mathrm{B}$ lymphocytes, osteoblasts, hepatocytes, and endothelial cells, among others (Tables 2-4). These receptors have a number of effects on cells that can influence outcome after trauma. It is now well known that activation of neuronal mGluR1 exacerbates necrosis, and mGluR1 activation has also been shown to increase permeability of endothelial cells after injury, which may exacerbate inflammation and injury. mGluR5 activation in neurons deters neuronal apoptosis, and provides protection in oligodendrocytes exposed to oxidative stress. Stimulation of the group II

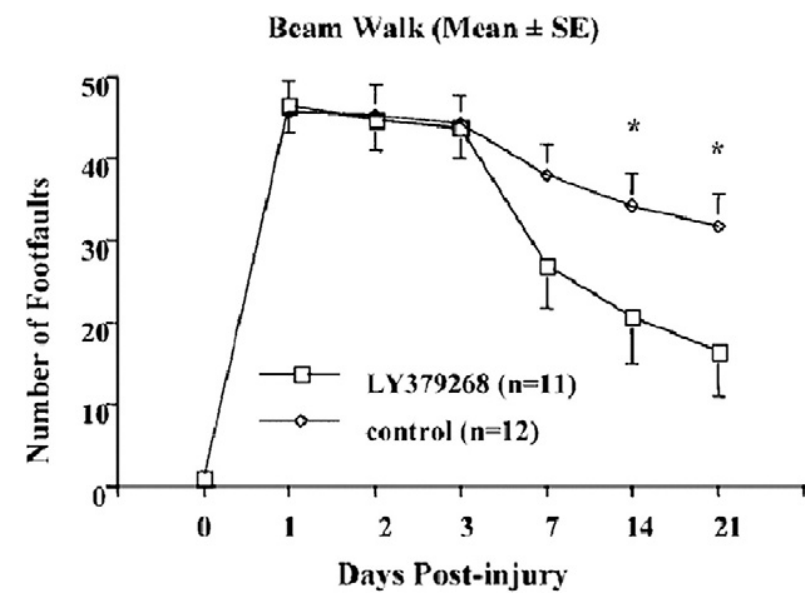

FIG. 6. Treatment with LY379268 improved motor recovery after brain injury in mice. A beam walking task was used to discriminate fine motor coordination differences between treated and control animals that had been subjected to controlled cortical impact injury. LY379268 or vehicle was administered intravenously at $30 \mathrm{~min}$ after trauma. A repeated-measures analysis of variance (ANOVA) yielded significant differences between these two groups $(p<0.05)$ at days 14 and 21 . Reproduced with permission from Movsesyan and Faden. ${ }^{33}$ For abbreviations, see abbreviation list. 
and III mGluRs is neuroprotective, reducing neuronal death after a variety of mechanical or chemical injuries. In microglia, activation of mGluR5, mGluR3, and group III mGluRs has an anti-inflammatory effect, reducing neurotoxicity and production of inflammatory mediators. mGluR5 also exerts anti-inflammatory effects when activated in T lymphocytes. mGluR2 stimulation, on the other hand, promotes a neurotoxic microglial phenotype. Stimulation of mGluR3 and group III mGluRs in astrocytes may also have neuroprotective effects, stimulating growth factor expression and glutamate clearance.

Modulation of mGluRs represents an attractive multipotential therapeutic strategy for both acute and chronic neurodegenerative disorders. In vivo, the activation of mGluR5 and group II and III mGluRs has been met with improved recovery after both traumatic brain injury and spinal cord injury, and antagonism of mGluR1 has similar effects, reflecting the multiple actions of these receptors in vitro.

Potential therapeutic effects of mGluR modulation include reduction of inflammation, decreased excitotoxicity, and inhibition of both necrotic and apoptotic cell death. The treatment regimen must be optimized for each injury or neurodegenerative model, however, with a focus on time of application and dose to most appropriately respond to each situation. The response of individual cell types to injury or disease was briefly reviewed here, and should be considered when applying mGluR agonists or antagonists as multipotential treatment strategies. For example, the increase in proliferation of microglia occurs quickly after spinal cord injury, and is maintained for months, ${ }^{92}$ suggesting a long therapeutic window for mGluR5 modification of microglial-mediated inflammation after spinal cord injury. Furthermore, mGluR $2 / 3$ is chronically increased in neurons after spinal cord injury, ${ }^{6}$ suggesting the possibility of delayed treatments.

Much research remains to be done to fully characterize the potential targets and therapeutic approaches to optimize mGluRs as a multipotential intervention. Recent reviews extensively outline critical considerations for the development of multitarget-directed ligands for treatment of neurodegenerative disorders. ${ }^{10,93}$

Acknowledgments: This work was supported by two U.S. National Institutes of Health R01 grants (5R01NS052568-03 and 5R01NS054221-02).

Abbreviations: $4 \mathrm{CPG}=(\mathrm{S})-4$-carboxyphenylglycine, 6-OHDA $=6$-hydroxydopamine, $\mathrm{A} \beta=\beta$-amyloid, AIDA $=$ 1-aminoindan-1, 5-dicarboxylic acid, ALS = amyotrophic lateral sclerosis, AMPA = alpha-amino-3-hydroxy-5-methyl-4isoxazolepropionic acid, APDC $=$ aminopyrrolidine-2,4-decarboxylate, $\mathrm{BBB}=$ Basso-Beattie-Bresnahan scale, cAMP $=$ cyclic adenosine monophosphate, $\mathrm{CHPG}=(\mathrm{RS})-2$-Chloro-5-hydroxyphenylglycine, $\mathrm{CGA}=$ chromogranin $\mathrm{A}, \mathrm{CNS}=$ central nervous system, $\mathrm{CPCCOEt}=7$-(hydroxyimino)cyclopropa[b]chromen- la-carboxylate ethyl ester, DCG-IV = $\left(2 \mathrm{~S}, 2^{\prime} \mathrm{R}, 3^{\prime} \mathrm{R}\right)-2-\left(2^{\prime}, 3^{\prime}-\right.$ Dicarboxycyclopropyl)glycine, DHPG $=(\mathrm{S})-3,5$-dihydroxyphenylglycine, EGLU $=2 S-\alpha$-ethylglutamic acid, ERK $=$ extracellular signal-regulated kinase, LAP4 = L-(+)-2-amino-4-phosphonobutyrate, L-CCG-I = (2S,1'S,2'S)-2-(carboxycyclopropyl)glycine, $\mathrm{LDH}=$ lactate dehydrogenase, $\mathrm{LPS}=$ lipopolysaccharide, $\mathrm{L}-\mathrm{SOP}=$ L-serine-O-phosphate, LTP = long-term potentiation, LY354740 = 1S,2S,5R,6S-2-aminobicyclo[3.1.0] hexane-2,6-dicarboxylate monohydrate, LY367385 = (+)-2-Methyl-4-carboxyphenylglycine, LY379268 = (-)-2-oxa-4-aminobicylco hexane-4,6-dicarboxylic acid, $\mathrm{MCPG}=\alpha$-methyl-4-carboxyphenylglycine, $\mathrm{mGluR}=$ metabotropic glutamate receptor, MAPK $=$ mitogen-activated protein kinase, MPEP = 2-methyl-6-(phenylethynyl)-pyridine, MTEP = 3-[(2-methyl-1,3-thiazol-4-yl)ethynyl]-pyridine, MS = multiple sclerosis, $\mathrm{NAAG}=\mathrm{N}$-Acetyl-aspartyl-glutamate, $\mathrm{NO}=$ nitric oxide, NMDA = N-methyl-D-aspartic acid, $\mathrm{PD}=$ Parkinson's disease, PLC $=$ phospholipase $\mathrm{C}, \mathrm{PAF}=$ platelet activating factor, $\mathrm{PI}=$ polyphosphoinositide, $\mathrm{PSD}=$ postsynaptic density, $\mathrm{PKC}=$ protein kinase $\mathrm{C}, \mathrm{ROS}=$ reactive oxygen species, $\mathrm{SCI}=$ spinal cord injury, TGF $-\beta=$ transforming growth factor $-\beta$, TBI $=$ traumatic brain injury, $\mathrm{TH}=$ tyrosine hyrdoxylase, YM-202074 $=\mathrm{N}$ cyclohexyl-6-\{[(2-methoxyethyl)(methyl)amino]methyl $\}-\mathrm{N}$ methylthiazolo $[3,2$-a]benzimidazole-2-carboxamide.

\section{REFERENCES}

1. Dingledine R, Borges K, Bowie D, Traynelis SF. The glutamate receptor ion channels. Pharmacol Rev 1999;51:7-61.

2. Karim F, Wang CC, Gereau RW 4th. Metabotropic glutamate receptor subtypes 1 and 5 are activators of extracellular signalregulated kinase signaling required for inflammatory pain in mice. J Neurosci 2001;21:3771-3779.

3. Warwick HK, Nahorski SR, Challiss RA. Group I metabotropic glutamate receptors, mGlu1a and mGlu5a, couple to cyclic AMP response element binding protein (CREB) through a common $\mathrm{Ca}^{2+}$ - and protein kinase C-dependent pathway. J Neurochem 2005;93:232-245

4. Demediuk P, Daly MP, Faden AI. Effect of impact trauma on neurotransmitter and nonneurotransmitter amino acids in rat spinal cord. J Neurochem 1989;52:1529-1536.

5. Faden AI, Demediuk P, Panter SS, Vink R. The role of excitatory amino acids and NMDA receptors in traumatic brain injury. Science 1989;244:798-800.

6. Gwak YS, Hulsebosch CE. Upregulation of group I metabotropic glutamate receptors in neurons and astrocytes in the dorsal horn following spinal cord injury. Exp Neurol 2005;195:236-243.

7. Mills CD, Fullwood SD, Hulsebosch CE. Changes in metabotropic glutamate receptor expression following spinal cord injury. Exp Neurol 2001;170:244-257.

8. Kaiser S, Nisenbaum LK. Evaluation of common gene expression patterns in the rat nervous system. Physiol Genomics 2003; $16: 1-7$.

9. Morphy R, Rankovic Z. Designed multiple ligands: an emerging drug discovery paradigm. J Med Chem 2005;48:6523-6543.

10. Van der Schyf CJ, Mandel S, Geldenhuys WJ, et al. Novel multifunctional anti-Alzheimer drugs with various CNS neurotransmitter targets and neuroprotective moieties. Curr Alzheimer Res 2007;4:522-536.

11. Faden AI, Stoica B. Neuroprotection: challenges and opportunities. Arch Neurol 2007;64:794-800.

12. Ferraguti F, Shigemoto R. Metabotropic glutamate receptors. Cell Tissue Res 2006;326:483-504.

13. Mudo G, Trovato-Salinaro A, Caniglia G, Cheng Q, Condorelli DF. Cellular localization of mGluR3 and mGluR5 mRNAs in normal and injured rat brain. Brain Res 2007;1149:1-13.

14. Ure J, Baudry M, Perassolo M. Metabotropic glutamate receptors and epilepsy. J Neurol Sci 2006;247:1-9.

15. Zhong J, Gerber G, Kojic L, Randic M. Dual modulation of excitatory synaptic transmission by agonists at group I metabotropic glutamate receptors in the rat spinal dorsal horn. Brain Res 2000;887:359-377. 
16. Bruno V, Copani A, Knöpfel T, et al. Activation of metabotropic glutamate receptors coupled to inositol phospholipid hydrolysis amplifies NMDA-induced neuronal degeneration in cultured cortical cells. Neuropharmacology 1995;34:1089-1098.

17. Allen JW, Knoblach SM, Faden AI. Activation of group I metabotropic glutamate receptors reduces neuronal apoptosis but increases necrotic cell death in vitro. Cell Death Differ 2000;7: 470-476.

18. Allen JW, Vicini S, Faden AI. Exacerbation of neuronal cell death by activation of group I metabotropic glutamate receptors: role of NMDA receptors and arachidonic acid release. Exp Neurol 2001;169:449-460.

19. Sapirstein A, Bonventre JV. Phospholipases A2 in ischemic and toxic brain injury. Neurochem Res 2000;25:745-753.

20. Faden AI, O'Leary DM, Fan L, Bao W, Mullins PG, Movsesyan VA. Selective blockade of the mGluR1 receptor reduces traumatic neuronal injury in vitro and improves outcome after brain trauma. Exp Neurol 2001;167:435-444.

21. Mukhin AG, Ivanova SA, Faden AI. mGluR modulation of posttraumatic neuronal death: role of NMDA receptors. Neuroreport 1997;8:2561-2566.

22. O'Leary DM, Movsesyan V, Vicini S, Faden AI. Selective mGluR5 antagonists MPEP and SIB-1893 decrease NMDA or glutamate-mediated neuronal toxicity through actions that reflect NMDA receptor antagonism. Br J Pharmacol 2000;131:1429_ 1437.

23. Lea PM 4th, Movsesyan VA, Faden AI. Neuroprotective activity of the mGluR5 antagonists MPEP and MTEP against acute excitotoxicity differs and does not reflect actions at mGluR5 receptors. Br J Pharmacol 2005;145:527-534.

24. Allen JW, Eldadah BA, Faden AI. $\beta$-Amyloid-induced apoptosis of cerebellar granule cells and cortical neurons: exacerbation by selective inhibition of group I metabotropic glutamate receptors. Neuropharmacology 1999;38:1243-1252.

25. Vincent AM, TenBroeke M, Maiese K. Metabotropic glutamate receptors prevent programmed cell death through the modulation of neuronal endonuclease activity and intracellular pH. Exp Neurol 1999;155:79-94.

26. Movsesyan VA, Stoica BA, Faden AI. mGluR5 activation reduces $\beta$-amyloid-induced cell death in primary neuronal cultures and attenuates translocation of cytochrome $c$ and apoptosis-inducing factor. J Neurochem 2004;89:1528-1536.

27. Zhu P, DeCoster MA, Bazan NG. Interplay among platelet-activating factor, oxidative stress, and group I metabotropic glutamate receptors modulates neuronal survival. J Neurosci Res 2004; 77:525-531.

28. Vincent AM, Maiese K. The metabotropic glutamate system promotes neuronal survival through distinct pathways of programmed cell death. Exp Neurol 2000;166:65-82.

29. Maiese K, Greenberg R, Boccone L, Swiriduk M. Activation of the metabotropic glutamate receptor is neuroprotective during nitric oxide toxicity in primary hippocampal neurons of rats. Neurosci Lett 1995;194:173-176.

30. Bond A, Ragumoorthy N, Monn JA, et al. LY379268, a potent and selective group II metabotropic glutamate receptor agonist, is neuroprotective in gerbil global, but not focal, cerebral ischaemia. Neurosci Lett 1999;273:191-194.

31. Sabelhaus CF, Schroder UH, Breder J, Henrich-Noack P, Reymann KG. Neuroprotection against hypoxic/hypoglycaemic injury after the insult by the group III metabotropic glutamate receptor agonist (R,S)-4-phosphonophenylglycine. Br J Pharmacol 2000;131:655-658.

32. Copani A, Bruno V, Battaglia G, et al. Activation of metabotropic glutamate receptors protects cultured neurons against apoptosis induced by beta-amyloid peptide. Mol Pharmacol 1995;47:890897.

33. Movsesyan VA, Faden AI. Neuroprotective effects of selective group II mGluR activation in brain trauma and traumatic neuronal injury. J Neurotrauma 2006;23:117-127.

34. Allen JW, Ivanova SA, Fan L, Espey MG, Basile AS, Faden AI. Group II metabotropic glutamate receptor activation attenuates traumatic neuronal injury and improves neurological recovery after traumatic brain injury. J Pharmacol Exp Ther 1999;290: 112-120.

35. Faden AI, Ivanova SA, Yakovlev AG, Mukhin AG. Neuroprotective effects of group III mGluR in traumatic neuronal injury. J Neurotrauma 1997;14:885-895.

36. Biber K, Laurie DJ, Berthele A, et al. Expression and signaling of group I metabotropic glutamate receptors in astrocytes and microglia. J Neurochem 1999;72:1671-1680.

37. Geurts JJ, Wolswijk G, Bö L, et al. Altered expression patterns of group I and II metabotropic glutamate receptors in multiple sclerosis. Brain 2003;126:1755-1766.

38. Byrnes KR, Stoica B, Loane DJ, Riccio A, Davis MI, Faden AI Metabotropic glutamate receptor 5 activation inhibits microglial associated inflammation and neurotoxicity. Glia 2008 Sep 24 [Epub ahead of print].

39. Taylor DL, Diemel LT, Cuzner ML, Pocock JM. Activation of group II metabotropic glutamate receptors underlies microglial reactivity and neurotoxicity following stimulation with chromogranin A, a peptide up-regulated in Alzheimer's disease. J Neurochem 2002;82:1179-1191.

40. Pinteaux-Jones F, Sevastou IG, Fry VA, Heales S, Baker D, Pocock JM. Myelin-induced microglial neurotoxicity can be controlled by microglial metabotropic glutamate receptors. J Neurochem 2008;106:442-454.

41. Taylor DL, Diemel LT, Pocock JM. Activation of microglial group III metabotropic glutamate receptors protects neurons against microglial neurotoxicity. J Neurosci 2003;23:2150-2160.

42. Geurts JJ, Wolswijk G, Bö L, et al. Expression patterns of group III metabotropic glutamate receptors mGluR4 and mGluR8 in multiple sclerosis lesions. J Neuroimmunol 2005;158:182-190.

43. Schools GP, Kimelberg HK. mGluR3 and mGluR5 are the predominant metabotropic glutamate receptor mRNAs expressed in hippocampal astrocytes acutely isolated from young rats. J Neurosci Res 1999;58:533-543.

44. Cai Z, Schools GP, Kimelberg HK. Metabotropic glutamate receptors in acutely isolated hippocampal astrocytes: developmental changes of mGluR5 mRNA and functional expression. Glia 2000;29:70-80

45. Romano C, Sesma MA, McDonald CT, O’Malley K, Van den Pol AN, Olney JW. Distribution of metabotropic glutamate receptor mGluR5 immunoreactivity in rat brain. J Comp Neurol 1995;355: 455-469.

46. Balázs R, Miller S, Romano C, de Vries A, Chun Y, Cotman CW Metabotropic glutamate receptor mGluR5 in astrocytes: pharmacological properties and agonist regulation. J Neurochem 1997; 69:151-163.

47. Condorelli DF, Dell'Albani P, Amico C, et al. Development profile of metabotropic glutamate receptor mRNA in rat brain Mol Pharmacol 1992;41:660-664.

48. Miller S, Romano C, Cotman CW. Growth factor upregulation of a phosphoinositide-coupled metabotropic glutamate receptor in cortical astrocytes. J Neurosci 1995;15:6103-6109.

49. Silva GA, Theriault E, Mills LR, Pennefather PS, Feeney CJ. Group I and II metabotropic glutamate receptor expression in cultured rat spinal cord astrocytes. Neurosci Lett 1999;263:117120.

50. Aronica E, Catania MV, Geurts J, Yankaya B, Troost D. Immunohistochemical localization of group I and II metabotropic glutamate receptors in control and amyotrophic lateral sclerosis human spinal cord: upregulation in reactive astrocytes. Neuroscience 2001;105:509-520.

51. Aronica E, van Vliet EA, Mayboroda OA, Troost D, da Silva FH, Gorter JA. Upregulation of metabotropic glutamate receptor subtype mGluR3 and mGluR5 in reactive astrocytes in a rat model of mesial temporal lobe epilepsy. Eur J Neurosci 2000;12:23332344.

52. Ferraguti F, Corti C, Valerio E, Mion S, Xuereb J. Activated astrocytes in areas of kainate-induced neuronal injury upregulate the expression of the metabotropic glutamate receptors $2 / 3$ and 5 . Exp Brain Res 2001;137:1-11.

53. Ulas J, Satou T, Ivins KJ, Kesslak JP, Cotman CW, Balázs R. Expression of metabotropic glutamate receptor 5 is increased in 
astrocytes after kainate-induced epileptic seizures. Glia 2000;30:352-361.

54. Nakahara K, Okada M, Nakanishi S. The metabotropic glutamate receptor mGluR5 induces calcium oscillations in cultured astrocytes via protein kinase C phosphorylation. J Neurochem 1997; 69:1467-1475.

55. Pasti L, Volterra A, Pozzan T, Carmignoto G. Intracellular calcium oscillations in astrocytes: a highly plastic, bidirectional form of communication between neurons and astrocytes in situ. J Neurosci 1997; 17:7817-7830.

56. Peavy RD, Conn PJ. Phosphorylation of mitogen-activated protein kinase in cultured rat cortical glia by stimulation of metabotropic glutamate receptors. J Neurochem 1998;71:603-612.

57. Servitja JM, Masgrau R, Sarri E, Picatoste F. Group I metabotropic glutamate receptors mediate phospholipase D stimulation in rat cultured astrocytes. J Neurochem 1999;72:1441-1447.

58. Ohishi H, Neki A, Mizuno N. Distribution of a metabotropic glutamate receptor, mGluR2, in the central nervous system of the rat and mouse: an immunohistochemical study with a monoclonal antibody. Neurosci Res 1998;30:65-82.

59. Petralia RS, Wang YX, Niedzielski AS, Wenthold RJ. The metabotropic glutamate receptors, mGluR2 and mGluR3, show unique postsynaptic, presynaptic and glial localizations. Neuroscience 1996;71:949-976.

60. Aronica E, Gorter JA, IJlst-Keizers H, et al. Expression and functional role of mGluR3 and mGluR5 in human astrocytes and glioma cells: opposite regulation of glutamate transporter proteins. Eur J Neurosci 2003;17:2106-2118.

61. Ciccarelli R, Sureda FX, Casabona G, et al. Opposite influence of the metabotropic glutamate receptor subtypes mGlu3 and -5 on astrocyte proliferation in culture. Glia 1997;21:390-398.

62. Moldrich RX, Aprico K, Diwakarla S, O'Shea RD, Beart PM. Astrocyte mGlu(2/3)-mediated cAMP potentiation is calcium sensitive: studies in murine neuronal and astrocyte cultures. Neuropharmacology 2002;43:189-203.

63. Winder DG, Ritch PS, Gereau RW 4th, Conn PJ. Novel glialneuronal signalling by coactivation of metabotropic glutamate and beta-adrenergic receptors in rat hippocampus. J Physiol 1996; 494 (Pt 3):743-755.

64. D’Onofrio M, Cuomo L, Battaglia G, et al. Neuroprotection mediated by glial group-II metabotropic glutamate receptors requires the activation of the MAP kinase and the phosphatidylinositol-3-kinase pathways. J Neurochem 2001;78:435-445.

65. Bruno V, Battaglia G, Casabona G, Copani A, Caciagli F, Nicoletti F. Neuroprotection by glial metabotropic glutamate receptors is mediated by transforming growth factor- $\beta$. J Neurosci 1998; 18:9594-9600.

66. Ciccarelli R, D'Alimonte I, Ballerini P, et al. Molecular signalling mediating the protective effect of A1 adenosine and mGlu3 metabotropic glutamate receptor activation against apoptosis by oxygen/glucose deprivation in cultured astrocytes. Mol Pharmacol 2007;71:1369-1380.

67. Besong G, Battaglia G, D'Onofrio M, et al. Activation of group III metabotropic glutamate receptors inhibits the production of RANTES in glial cell cultures. J Neurosci 2002;22:5403-5411.

68. Maiese K, Chong ZZ, Li F. Driving cellular plasticity and survival through the signal transduction pathways of metabotropic glutamate receptors. Curr Neurovasc Res 2005;2:425-446.

69. Deng W, Wang H, Rosenberg PA, Volpe JJ, Jensen FE. Role of metabotropic glutamate receptors in oligodendrocyte excitotoxicity and oxidative stress. Proc Natl Acad Sci U S A 2004;101: $7751-7756$.

70. Luyt K, Varadi A, Halfpenny CA, Scolding NJ, Molnar E. Metabotropic glutamate receptors are expressed in adult human glial progenitor cells. Biochem Biophys Res Commun 2004;319: $120-129$.

71. Luyt K, Varadi A, Molnar E. Functional metabotropic glutamate receptors are expressed in oligodendrocyte progenitor cells. J Neurochem 2003;84:1452-1464.

72. Pacheco R, Ciruela F, Casadó V, et al. Group I metabotropic glutamate receptors mediate a dual role of glutamate in $\mathrm{T}$ cell activation. J Biol Chem 2004;279:33352-33358.

73. Boldyrev AA, Carpenter DO, Johnson P. Emerging evidence for a similar role of glutamate receptors in the nervous and immune systems. J Neurochem 2005;95:913-918.

74. Benarroch EE. Metabotropic glutamate receptors: synaptic modulators and therapeutic targets for neurologic disease. Neurology 2008;70:964-968.

75. Mills CD, Johnson KM, Hulsebosch CE. Group I metabotropic glutamate receptors in spinal cord injury: roles in neuroprotection and the development of chronic central pain. J Neurotrauma 2002; 19:23-42.

76. Lyeth BG, Gong QZ, Shields S, Muizelaar JP, Berman RF. Group I metabotropic glutamate antagonist reduces acute neuronal degeneration and behavioral deficits after traumatic brain injury in rats. Exp Neurol 2001;169:191-199.

77. Kohara A, Takahashi M, Yatsugi S, et al. Neuroprotective effects of the selective type 1 metabotropic glutamate receptor antagonist YM-202074 in rat stroke models. Brain Res 2008;1191:168-179.

78. Topolnik L, Azzi M, Morin F, Kougioumoutzakis A, Lacaille JC. mGluR1/5 subtype-specific calcium signalling and induction of long-term potentiation in rat hippocampal oriens/alveus interneurones. J Physiol 2006;575:115-131.

79. Eder C. Ion channels in microglia (brain macrophages). Am J Physiol 1998;275:C327-C342.

80. Lea PM, Custer SJ, Vicini S, Faden AI. Neuronal and glial mGluR5 modulation prevents stretch-induced enhancement of NMDA receptor current. Pharmacol Biochem Behav 2002;73: 287-298.

81. Bao WL, Williams AJ, Faden AI, Tortella FC. Selective mGluR5 receptor antagonist or agonist provides neuroprotection in a rat model of focal cerebral ischemia. Brain Res 2001;922:173-179.

82. Vernon AC, Zbarsky V, Datla KP, Croucher MJ, Dexter DT. Subtype selective antagonism of substantia nigra pars compacta group I metabotropic glutamate receptors protects the nigrostriatal system against 6-hydroxydopamine toxicity in vivo. J Neurochem 2007;103:1075-1091.

83. Pinheiro PS, Mulle C. Presynaptic glutamate receptors: physiological functions and mechanisms of action. Nat Rev Neurosci 2008;9:423-436.

84. Venero JL, Santiago M, Tomás-Camardiel M, Matarredona ER, Cano J, Machado A. DCG-IV but not other group-II metabotropic receptor agonists induces microglial BDNF mRNA expression in the rat striatum: correlation with neuronal injury. Neuroscience 2002;113:857-869.

85. Matarredona ER, Santiago M, Venero JL, Cano J, Machado A. Group II metabotropic glutamate receptor activation protects striatal dopaminergic nerve terminals against MPP+-induced neurotoxicity along with brain-derived neurotrophic factor induction. J Neurochem 2001;76:351-360.

86. Mills CD, Johnson KM, Hulsebosch CE. Role of group II and group III metabotropic glutamate receptors in spinal cord injury. Exp Neurol 2002;173:153-167.

87. Bruno V, Battaglia G, Ksiazek I, et al. Selective activation of mGlu4 metabotropic glutamate receptors is protective against excitotoxic neuronal death. J Neurosci 2000;20:6413-6420.

88. Zhong C, Zhao X, Sarva J, Kozikowski A, Neale JH, Lyeth BG. NAAG peptidase inhibitor reduces acute neuronal degeneration and astrocyte damage following lateral fluid percussion TBI in rats. J Neurotrauma 2005;22:266-276.

89. Lee HG, Zhu X, O'Neill MJ, et al. The role of metabotropic glutamate receptors in Alzheimer's disease. Acta Neurobiol Exp (Wars) 2004;64:89-98.

90. Rouse ST, Marino MJ, Bradley SR, Awad H, Wittmann M, Conn PJ. Distribution and roles of metabotropic glutamate receptors in the basal ganglia motor circuit: implications for treatment of Parkinson's disease and related disorders. Pharmacol Ther 2000; 88:427-435.

91. Bradley SR, Marino MJ, Wittmann M, et al. Activation of group II metabotropic glutamate receptors inhibits synaptic excitation of the substantia nigra pars reticulata. J Neurosci 2000;20:3085-3094.

92. Byrnes KR, Garay J, Di Giovanni S, et al. Expression of two temporally distinct microglia-related gene clusters after spinal cord injury. Glia 2006;53:420-433. 
93. Cavalli A, Bolognesi ML, Minarini A, et al. Multi-target-directed ligands to combat neurodegenerative diseases. J Med Chem 2008; $51: 347-372$.

94. Verkhratsky A, Kirchhoff F. Glutamate-mediated neuronal-glial transmission. J Anat 2007;210:651-660.

95. Rezzani R, Corsetti G, Rodella L, Angoscini P, Lonati C, Bianchi R. Cyclosporine-A treatment inhibits the expression of metabotropic glutamate receptors in rat thymus. Acta Histochem 2003; 105:81-87.

96. Storto M, de Grazia U, Knöpfel T, et al. Selective blockade of mGlu5 metabotropic glutamate receptors protects rat hepatocytes against hypoxic damage. Hepatology 2000;31:649-655.

97. Shin SS, Namkoong J, Wall BA, Gleason R, Lee HJ, Chen S. Oncogenic activities of metabotropic glutamate receptor 1 (Grm1) in melanocyte transformation. Pigment Cell Melanoma Res 2008;21:368-378.

98. Frati C, Marchese C, Fisichella G, et al. Expression of functional mGlu5 metabotropic glutamate receptors in human melanocytes. J Cell Physiol 2000;183:364-372.
99. Luyt K, Varadi A, Durant CF, Molnar E. Oligodendroglial metabotropic glutamate receptors are developmentally regulated and involved in the prevention of apoptosis. J Neurochem 2006; 99:641-656.

100. Collard CD, Park KA, Montalto MC, et al. Neutrophil-derived glutamate regulates vascular endothelial barrier function. J Biol Chem 2002;277:14801-14811.

101. Yao HH, Ding JH, Zhou F, et al. Enhancement of glutamate uptake mediates the neuroprotection exerted by activating group II or III metabotropic glutamate receptors on astrocytes. J Neurochem 2005;92:948-961.

102. Hinoi E, Fujimori S, Nakamura Y, Yoneda Y. Group III metabotropic glutamate receptors in rat cultured calvarial osteoblasts. Biochem Biophys Res Commun 2001;281:341-346.

103. Foreman MA, Gu Y, Howl JD, Jones S, Publicover SJ. Group III metabotropic glutamate receptor activation inhibits $\mathrm{Ca}^{2+}$ influx and nitric oxide synthase activity in bone marrow stromal cells. J Cell Physiol 2005;204:704-713. 